\title{
A Thermodynamic Approach to Ohmic Contact Formation to p-GaN
}

Bo Liu', Mikko H. Ahonen and Paul H. Holloway

Department of Materials Science and Engineering

University of Florida, Gainesville, FL 32611-6400

\section{ABSTRACT}

A new ohmic contact scheme for gallium nitride is presented. The use of Nitrideforming metal Over Gallide-forming metal, "NOG", can modify the thermodynamic activity of $\mathrm{N}$ and Ga near the interface. This in turn can modify the near-surface point defect concentrations, particularly the vacancies of $\mathrm{Ga}$ and $\mathrm{N}$. The principle of this contact scheme was shown to be consistent with results from $\mathrm{Ni} / \mathrm{Au}, \mathrm{Ni} / \mathrm{Zn}-\mathrm{Au}, \mathrm{Ta} / \mathrm{Ti}$, and $\mathrm{Ni} / \mathrm{Mg} / \mathrm{Ni} / \mathrm{Si}$ contacts. In the present study, the "NOG" scheme was used to design $\mathrm{Ni} / \mathrm{Ti} / \mathrm{Au}$ and $\mathrm{Ni} / \mathrm{Al} / \mathrm{Au}$ metallization, and addition of $\mathrm{Ti}$ and $\mathrm{Al}$ nitride-forming metals to the Ni gallide-forming metal led to lower but still high contact resistance. Ti was shown to be better than $\mathrm{Al}$ as the nitride-forming metal based on the decrease of resistance in as deposited contacts. Compared to $\mathrm{Ni} / \mathrm{Au}$, four times more current was measured in $\mathrm{Ni} / \mathrm{Ti} / \mathrm{Au}$ contacts to $\mathrm{p}-\mathrm{GaN}$ after anneal at $300^{\circ} \mathrm{C}$ for $5 \mathrm{~min}$. However the addition of the Ti nitride-forming metal led to lower stability at $500^{\circ} \mathrm{C}$.

\section{INTRODUCTION}

$\mathrm{GaN}$ alloys have received great interest in the past decade due to applications in photonic and electronic devices. However, because of the low free hole concentrations of $\mathrm{p}-\mathrm{GaN}\left(10^{17} \mathrm{~cm}^{-3}\right)$ and lack of a metal with a work function $\phi$ equal to or greater than the bandgap plus electron affinity $\left(\mathrm{E}_{\mathrm{g}}+\chi_{\mathrm{s}}=7.5 \mathrm{eV}\right)$, attempts to make low resistance ohmic contacts to $\mathrm{p}-\mathrm{GaN}$ have been unsuccessful[1-12].

The purpose of this paper is to propose a general scheme by which metallization schemes for ohmic contacts can be systematically selected. The scheme is called "NOG" (Nitride-forming metal Over Gallide-forming metal) and is based on the thermodynamic stabilities of these phases during interfacial reactions between the metallization layers and the GaN semiconductor.

\section{PRINCIPLES OF “NOG” SCHEME}

Since as-grown $\mathrm{GaN}$ are intrinsically n-type, there may be a high concentration of native $\mathrm{N}$ vacancies, $\mathrm{V}_{\mathrm{N}}$, which is equivalent to a Ga-rich condition in the film. An opposite situation could be postulated: if a N-rich condition could be created in as-grown GaN films, the extra $\mathrm{N}$ atoms could create Ga vacancies and intrinsically $\mathrm{p}-\mathrm{GaN}$ films However, this postulated condition might still be achieved by interfacial reactions in the contact region. If extra $\mathrm{N}$ atoms could be kept between the contact metal layer and the bulk p-GaN film, a N-rich condition could be formed at the metal/GaN interface. The

\footnotetext{
${ }^{1}$ Electronic mail: bliu@ mail.mse.ufl.edu
} 
extra $\mathrm{N}$ atoms could fill the $\mathrm{V}_{\mathrm{N}}$ positions and create Ga vacancies which would act as acceptors. If the Ga vacancy acceptors were sufficiently shallow and reached a high concentration, the interfacial region could become $\mathrm{p}^{+}-\mathrm{GaN}$ and current transportation could be dominated by field emission or thermionic field emission.

The principle of the "NOG" scheme is illustrated in Figure 1. A gallide-forming metal is followed by a nitride-forming metal covered with a layer of protective metal (such as $\mathrm{Au}$ ). Under a suitable annealing condition, the gallide-forming metal would react with $\mathrm{GaN}$ to form stable gallides and release $\mathrm{N}$ atoms. This first metal layer must both dissociate the GaN lattice and prevent or slow down the process of nitrogen out-diffusion. The second nitride-forming metal would help keep the released $\mathrm{N}$ atoms at the contact interfacial region and create a $\mathrm{N}$-rich condition.

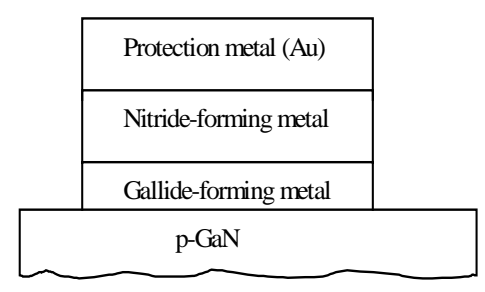

Figure 1. Principle of the "NOG" scheme.

all transition metals may be classified into three groups: the late, early and middle transition metals based on the enthalpy of the metallurgical reactions, which was called gallide-forming, nitride-forming and neutral metals in this paper. The metallurgical reaction of these metals to GaN was reported in reference [13] and [14].

\section{EXPLANATION OF LITERATURE}

Many studies have been reported along with postulated mechanisms to explain reduced contact resistance, such as $\mathrm{GaN}$ re-growth [12], $\mathrm{H}$ extraction [1] and $\mathrm{Ni}$ oxidation [2]. A few representative contact schemes will be discussed based on the principle of "NOG". Other contact schemes could be analyzed similarly.

The contact scheme Ni/Au [2, 3, 4, 5, 6] is widely used for GaN device fabrication. Based on the "NOG" principles, this scheme works due to the reaction between $\mathrm{Ni}$ and $\mathrm{GaN}$. The Ga would react with Ni to form stable gallides and reduce excess $\mathrm{Ga}$ atoms. Reduced excess $\mathrm{Ga}$ could be reflected as reduced concentration of $\mathrm{V}_{\mathrm{N}}$.Less compensation of acceptors would result in higher free hole concentrations in the interfacial region. Other reported contact schemes like $\mathrm{Pd} / \mathrm{Au}[7,8], \mathrm{Pt} / \mathrm{Au}[6,9,10], \mathrm{Pd} / \mathrm{Au} / \mathrm{Pt} / \mathrm{Au}[8]$, $\mathrm{Pd} / \mathrm{Pt} / \mathrm{Au}[6]$ and $\mathrm{Pt} / \mathrm{Ni} / \mathrm{Au}[11]$ contact schemes could be explained similarly.

A relatively low specific contact resistance $\left(3.6 \times 10^{-3} \Omega-\mathrm{cm}^{2}\right)$ was obtained with $\mathrm{Ni} / \mathrm{Zn}-\mathrm{Au}$ [12] in p-GaN with a carrier concentration of $\mathrm{N}_{\mathrm{h}}=4.4 \times 10^{17} \mathrm{~cm}^{-3}$. It was postulated that $\mathrm{Zn}$ was an acceptor and that the $\mathrm{Zn}$-Au alloy layer increased the interface carrier concentration. $\mathrm{Zn}$ is an acceptor, but it is deep $\left(\mathrm{E}_{\mathrm{A}}=570 \mathrm{meV}\right)[16]$ and therefore should not be ionized at room temperature. Based on the "NOG" scheme, the mechanism should be the same as the $\mathrm{Ni} / \mathrm{Au}$ scheme discussed above. The main reason for improved 
contact performance probably due to the limited time for native oxide to grow on GaN and the use of high vacuum for metallization. Optimum contact resistance would not be predicted for the $\mathrm{Ni} / \mathrm{Zn}$-Au because of no nitride forming component to the metallization. The released $\mathrm{N}$ atoms could be released as $\mathrm{N}_{2}$ rather than kept at the interface.

A low resistivity $\left(3.2 \times 10^{-5} \Omega-\mathrm{cm}^{2}\right)$ ohmic contact to $\mathrm{p}-\mathrm{GaN}$ was produced with $\mathrm{Ta} / \mathrm{Ti}$ after a high temperature anneal $\left(800^{\circ} \mathrm{C}\right.$ for $\left.20 \mathrm{~min}\right)$ [1]. The authors postulated that $\mathrm{Ta}$ and $\mathrm{Ti}$ were able to remove hydrogen from $\mathrm{Mg}-\mathrm{H}$ complexes and therefore reduced compensation of the acceptors. It was found that a dual layer structure formed better contacts than a single Ta or Ti layer. After a few days, the contact resistance increased to a much higher value. This was attributed to a reverse transport of compensating hydrogen from the Ti/Ta layers back into the interface region and recompensation of $\mathrm{Mg}$ acceptors. However, Fukai has reported that the enthalpy for $\mathrm{MgH}_{2}(-0.77 \mathrm{eV} /$ atom $)$ is more negative than for $\mathrm{TiH}_{2}\left(-0.68 \mathrm{eV} /\right.$ atom) or $\mathrm{TaH}_{0.5}(-0.417 \mathrm{eV} /$ atom) [17]. Thus for these reaction products, Ta and Ti should not reduce $\mathrm{MgH}_{2}$. In the "NOG" scheme, it would be postulated instead that $\mathrm{Ta}$ and $\mathrm{Ti}$ would dissociate the $\mathrm{GaN}$ and release $\mathrm{N}$ atoms. The released $\mathrm{N}$ atoms would increase the nitrogen chemical potential and result in reduced $\mathrm{V}_{\mathrm{N}}$ concentrations, in addition to forming $\mathrm{TaN}_{\mathrm{x}}$ and $\mathrm{TiN}_{\mathrm{x}}$ compounds. The differences in the thermodynamic and kinetic properties of Ta and Ti would explain why Ta/Ti form better contacts than Ta or Ti individually. The observation of an increased resistance with time at room temperature can also be explained using the "NOG" scheme since formation of stable nitrides would create $\mathrm{V}_{\mathrm{N}}$ and increase compensationof holes in the contact region.

For $\mathrm{Ni} / \mathrm{Mg} / \mathrm{Ni} / \mathrm{Si}[12]$, contact resistance value of $\approx 10^{-3} \Omega-\mathrm{cm}^{2}$ was measured. These ohmic contacts were degraded by annealing at $500^{\circ} \mathrm{C}$ for $20 \mathrm{~min}$. The authors postulated a similar mechanism of solid phase epitaxial regrowth known to occur for $\mathrm{AuGeNi} / \mathrm{GaAs}$ contacts[15]. The authors in the study of $\mathrm{Ni} / \mathrm{Mg} / \mathrm{Ni} / \mathrm{Si}$ postulated that regrowth of $\mathrm{GaN}$ and NiSi led to ohmic contacts. Using the principles of the "NOG" scheme, formation of an ohmic contact would result from Ni dissociation of the $\mathrm{GaN}$ and formation of $\mathrm{NiGa}_{\mathrm{x}}$, $\mathrm{MgN}_{\mathrm{x}}$ and $\mathrm{SiN}_{\mathrm{x}}$. The nitride phases would increase the activity of $\mathrm{N}$ in the interfacial region, which would create a $\mathrm{N}$-rich condition and a more p-type interface. This contact metallization is close to the "NOG" scheme under discussion.

This idea of interfacial reactions and control of vacancies which is the basic tenet of the "NOG" scheme can and does apply to ohmic contact to n-GaN, not just to p-GaN. Lester, et al. [18] reported that aluminum produced an ohmic contact of $10^{-3} \mathrm{ohm}-\mathrm{cm}^{2}$ to $\mathrm{n}-\mathrm{GaN}$. This is reasonable because of the matched work function of $\mathrm{Al}$ and $\mathrm{GaN}$ [15]. The contact resistance of $\mathrm{Al} / \mathrm{n}-\mathrm{GaN}$ increased by $50 \%$ upon annealing at $575^{\circ} \mathrm{C}$. The postulated reason was formation of a large bandgap AlN layer at the interface. The contact resistance was improved to $8 \times 10^{-6} \Omega-\mathrm{cm}^{2}$ using a Ti/Al bilayer metals annealed at $900^{\circ} \mathrm{C}$, presumably due to the formation of TiN at the interface of $\mathrm{Ti} / \mathrm{Al}$ (and $\mathrm{Ti} / \mathrm{Al} / \mathrm{Ni} / \mathrm{Au}$ ) contacts $[19,20]$. Depletion of $\mathrm{N}$ in the $\mathrm{GaN}$ surface region would create more $\mathrm{V}_{\mathrm{N}}$ vacancies, and result in an $\mathrm{n}^{+}-\mathrm{GaN}$ layer with improved electron tunneling, consistent with the "NOG" scheme.

\section{Experimental studies of $\mathrm{Ni} / \mathrm{Ti} / \mathrm{Au}$ and $\mathrm{Ni} / \mathrm{Al} / \mathrm{Au}$}

Besides analysis of published results, the "NOG" scheme was compared to experimental data collected from $\mathrm{Ni} / \mathrm{Ti} / \mathrm{Au}, \mathrm{Ni} / \mathrm{Al} / \mathrm{Au}$ and $\mathrm{Ni} / \mathrm{Au}$ contacts to $\mathrm{p}-\mathrm{GaN}$. Current-voltage (I-V) data showed that more current was obtained in the ternary layer contacts, consistent with predictions.

F99W11.78 
The $\mathrm{p}-\mathrm{GaN}$ wafers used in this experiment were purchased from SVT Associates. The GaN $1 \mu \mathrm{m}$ epilayers were grown by MBE and had a free hole concentration of 1.1 $2.5 \times 10^{17} \mathrm{~cm}^{-3}$. Samples were cleaned with agitated acetone (5min), methanol (5min) and boiling aqua regia $(10 \mathrm{~min})$ sequentially before being washed with DI water. All samples were blown dry with $\mathrm{N}_{2}$ gas between each step. The contacts were deposited at a base pressure of $\approx 5 \times 10^{-6}$ Torr.

Figure 2 shows the I-V data for (a) $50 \mathrm{~nm} \mathrm{Ni} / 50 \mathrm{~nm} \mathrm{Au}$ or $10 \mathrm{~nm} \mathrm{Ni} / 50 \mathrm{~nm} \mathrm{Al} / 50 \mathrm{~nm}$ $\mathrm{Au}$ contacts, and (b) for $10 \mathrm{~nm} \mathrm{Ni} / 200 \mathrm{~nm} \mathrm{Ti} / 200 \mathrm{~nm} \mathrm{Au}$ or $10 \mathrm{~nm} \mathrm{Ni} / 200 \mathrm{~nm} \mathrm{Al} / 200 \mathrm{~nm} \mathrm{Au}$. The current was a factor of two higher through $\mathrm{Ni} / \mathrm{Al} / \mathrm{Au}$ than through $\mathrm{Ni} / \mathrm{Au}$, and the current through $\mathrm{Ni} / \mathrm{Ti} / \mathrm{Au}$ was $30 \%$ higher than through $\mathrm{Ni} / \mathrm{Al} / \mathrm{Au}$.

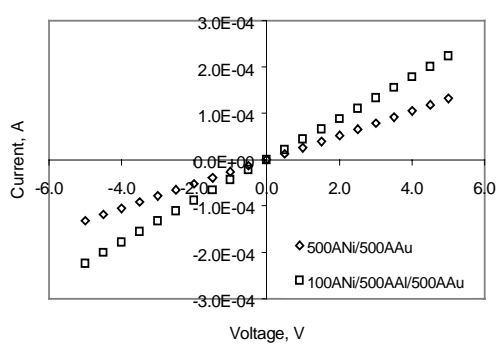

(a)

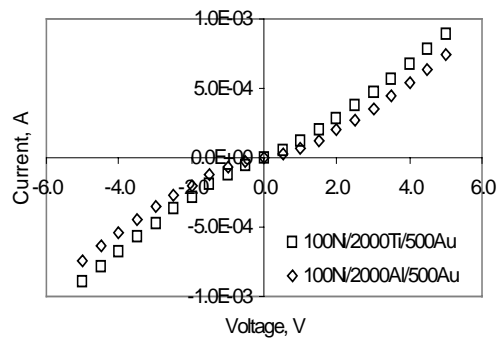

(b)

Figure 2 Effects of adding a nitride-forming metal to $\mathrm{Ni} / \mathrm{Au}$ as-deposited contacts to p-GaN (a) Ni/Au and Ni/Al/Au; (b) Ni/Ti/Au and Ni/Al/Au

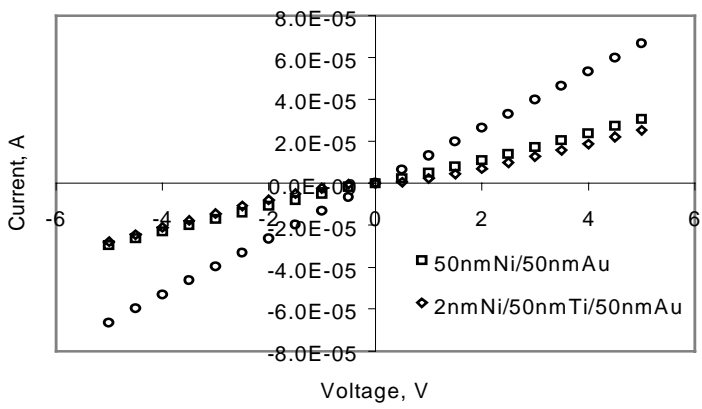

Figure 3 Effects of Ni thickness in the as deposited Ni/Ti/Au/p-GaN contacts

Based on the principles "NOG", the first Ni layer in both $\mathrm{Ni} / \mathrm{Ti} / \mathrm{Au}$ and $\mathrm{Ni} / \mathrm{Al} / \mathrm{Au}$ contacts was a gallide forming metal, which would release $\mathrm{N}$ atoms. This $\mathrm{Ni}$ layer also 
acts as a nitride-forming barrier because of slowed $\mathrm{N}$ diffusion. This would maintain a higher $\mathrm{N}$ activity at the $\mathrm{GaN}$ surface, reduce $\mathrm{V}_{\mathrm{N}}$, and result in less acceptor compenstion.

The effects of Ni thickness were studied by changing the Ni thickness (Figure 3). As the Ni changed from 2 to $10 \mathrm{~nm}$ the current increased by a factor of 3 . A higher contact resistance for thin gallide-forming metal $(2 \mathrm{~nm} \mathrm{Ni})$ could result from the extent of interfacial reaction being too limited to affect $V_{N}$ concentration or the Ni layer is too thin to prevent quick formation of stable nitride $\left(\mathrm{TiN}_{\mathrm{x}}\right)$ and thus to increase $\mathrm{V}_{\mathrm{N}}$ concentration.

The effects of annealing on $\mathrm{Ni} / \mathrm{Ti} / \mathrm{Au}$ and the $\mathrm{Ni} / \mathrm{Au}$ contacts are shown in Figure 4. Both $\mathrm{Ni} / \mathrm{Au}$ and $\mathrm{Ni} / \mathrm{Ti} / \mathrm{Au}$ have the same current for the as deposited samples. For $\mathrm{Ni} / \mathrm{Ti} / \mathrm{Au}$ contact, a $300^{\circ} \mathrm{C}, 30 \mathrm{sec}$ anneal resulted in slightly higher current, and a $5 \mathrm{~min}$ anneal at $300^{\circ} \mathrm{C}$ resulted in a four fold increase. The current through $\mathrm{Ni} / \mathrm{Ti} / \mathrm{Au}$ contacts annealed at $300^{\circ} \mathrm{C}, 30 \mathrm{sec}$ was similar to that measured for $\mathrm{Ni} / \mathrm{Au}$ contacts annealed at $300^{\circ} \mathrm{C}$ for $5 \mathrm{~min}$. After a $500^{\circ} \mathrm{C}, 5 \mathrm{~min}$ anneal, the current though $\mathrm{Ni} / \mathrm{Ti} / \mathrm{Au}$ contacts decreased to near that of as-deposited contacts. In contrast, the current in $\mathrm{Ni} / \mathrm{Au}$ contacts increased continually, even after annealing at $800^{\circ} \mathrm{C}$ for $30 \mathrm{sec}$. The higher as deposited current, but more serious degradation of the $\mathrm{Ni} / \mathrm{Ti} / \mathrm{Au}$ contact shows that while the nitride-forming metal (Ti) is helpful in reducing the contact resistance, it also leads to the contact instability. This would be consistent with continued reaction between $\mathrm{Ti}$ and $\mathrm{N}$ to form $\mathrm{TiN}_{\mathrm{x}}$ resulting in generation of too many $\mathrm{V}_{\mathrm{N}}$ 's.

The data in Figure 4 cannot be directly compared to those in Figure 3, since the contacts in Figure 3 are $0.5 \mathrm{~mm}$ diameter dots defined by a shadow mask, while those in Figure 4 are a TLM pattern with a $16 \mu \mathrm{m}$ spacing defined by photolithography.

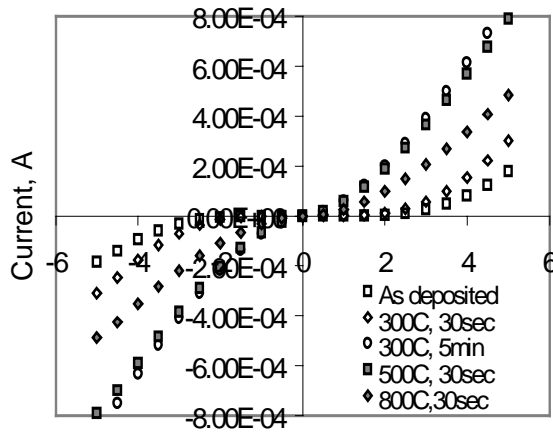

Voltage, V

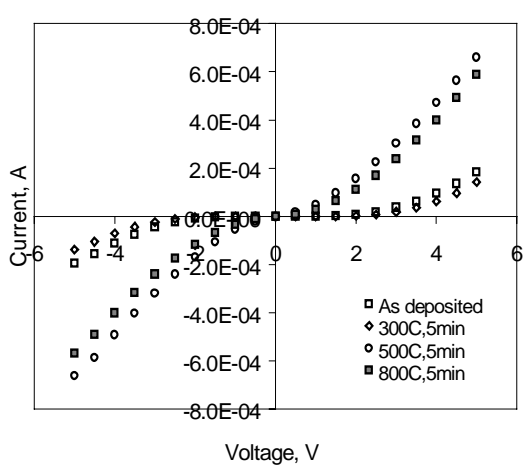

(b)

Figure 4 Effects of annealing on I-V data for (a)20nmNi/50nmTi/50nmAu; (b) $50 \mathrm{nmNi} / 50 \mathrm{nmAu}$ to $\mathrm{p}-\mathrm{GaN}$ 


\section{CONCLUSIONS}

A new ohmic contact scheme for $\mathrm{p}-\mathrm{GaN}$ called Nitride-forming metal Over Gallium-forming metals, "NOG", was proposed and discussed. Published results for ohmic contacts to p- or n-GaN were able to be explained qualitatively by the "NOG" principles. Lower contact resistances were found for contacts with both gallide and nitride forming metals $(\mathrm{Ni} / \mathrm{Al} / \mathrm{Au}$ and $\mathrm{Ni} / \mathrm{Ti} / \mathrm{Au})$, when compared with only a gallideforming $\mathrm{Ni} / \mathrm{Au}$ contacts.

\section{REFERENCES:}

1. M. Suzuki, T. Kawakami, T. Arai, S. Kobayashi, Y. Koide, T. Uemura, N. Shibata and M. Murakami, Appl. Phys. Lett., 1999, 74, 275

2. J.-K. Ho, C.-S. Jong, C. C. Chiu, C.-Y. Chen, Appl. Phys. Lett., 1999, 74, 1275

3. A. K. Fung, J. A. Borton, M. I NathanJ. M. V. Hove and R. Hickman, J. Elec. Mater., 1999, 28, 572

4. T. Kim, M. C. Yoo and T. Kim, III-V nitrides, MRS Symp. Proc., 1997, 449, 1061

5. H. Ishikawa, S. Kobayashi, Y. Koide, S. Yamasaki, S. Nagai, J. Umezaki, M. Koike and M. Murakami, J. of Appl. Phys., 2, 1997, 81, 1315

6. D. J. King, L. Zhang, J. C. Ramer, S. D. Hersee and L. F. Lester, III-V nitrides, MRS Symp. Proc. 1997, 468, 421

7. J. K. Kim, J.-L. Lee, J. W. Lee, H. E. Shin, Y. J. Park and T. Kim, Appl. Phys. Lett., 1998, 73, 2953

8. T. Kim, J. Khim, S. Chae and T. Kim, III-V nitrides, MRS Symp. Proc., 1997, 468, 427

9. T. Mori, T. Kozawa, T. Ohwaki, Y. Taga, S. Nagai, S. Yamasaki, S. Asami, N. Shibata and M. Koike, Appl. Phys. Lett.,1996, 69, 3537

10. M. C. Yoo, J. W. Lee, J. W. Myoung, K. H. Shim and K. Kim, MRS Symp. Proc., 1996, 423, 131

11. J.-S. Jang, I.-S. Chang, H.-K. Kim, T.-Y.Seong, S. Lee and S.-J. Park, Appl. Phys. Lett. 74, 70(1999)

12. D. H. Youn, M. Hao, H. Sato, T. Sugahara, Y. nao and S. Sakai, Jpn. J. Appl. Phys. 37, 1768(1998)

13. S. E. Mohney and X. Lin, Journal of Electronic Materials, 1996, 25, 811

14. S. E. Mohney, B. P. Luther, T. N. Jackson and M. A. Khan, MRS Symp. Proc. 395, 843(1996)

15. P.H. Holloway, T.-J. Kim, J.T. Trexler, S. Miller, J.J. Fijol, W.V. Lampert and T.W. Haas, Appl. Surf. Sci., 1997, 117/118, 362

16. J. I. Pankove, GaN and Related Materials, ed. S. J. Pearton, Gordon and Breach Science Publishers, Amsteredam, Netherlands, 1(1997)

17. Y. Fukai, Metal-Hydrogen System-basic bulk properties, Springer-Verlag, 31(1993)

18. L. F. Lester, J. M. Brown, J. C. Ramer, L. Ahang, S. D. Hersee and J. C. Zolper, Appl. Phys. Lett. 69, 2737(1996)

19. Z. F. Fan, S. N. Mohammad, W. Kim, O. Aktas, A. E. Botchkarev and H. Mokoc, Appl. Phys. Lett. 68, 1672(1996)

20. M. E. Lin, Z. Ma, F. Y. Huang, Z. F. Fan, L. H. Allen and H. Morkoc, Appl. Phys. Lett. 64, 1003(1994)

F99W11.78 